\title{
Eça e machado: do realismo naturalista ao realismo carnavalizado
}

\author{
Eça and machado: from naturalistic realism to carnavalized \\ realism
}

\author{
Sérgio SCHAEFER ${ }^{1}$ \\ (Universidade de Santa Cruz do Sul)
}

\begin{abstract}
RESUMO: Eça de Queirós, ao tomar o modelo realista-naturalista como referência para escrever seus dois romances - $O$ crime do padre Amaro e O primo Basilio - tende a desfigurar a verdade moral dos fatos e, com isso, a enfraquecer a dimensão propriamente artística da obra literária e dos personagens. Machado de Assis, em Memórias póstumas de Brás Cubas, ao usar o recurso carnavalizante do "defunto autor", recupera a figuração da verdade moral que deve estar presente na obra através das ações dos personagens e recobre o esqueleto realista de musculatura estética. Apesar das diferenças literárias entre os dois romancistas, é possível perceber que ambos contestam as aparências sociais. Por isso, é preciso reler com olhos críticos a crítica de Machado feita a Eça.
\end{abstract}

PALAVRAS-CHAVE: Realismo naturalista; realismo carnavalizado; figuração moral e artística; Eça de Queirós; Machado de Assis.

\begin{abstract}
Eça de Queirós, when taking the realist-naturalist model for reference in writing his two novels - $O$ crime do padre Amaro and O primo Basilio - tends to disfigure the truth of moral facts and thus weaken the proper dimension of artistic work and literary characters. Machado de Assis, in Memórias póstumas de Brás Cubas, when using the carnavalizante resource of the "deceased author" recovers the figuration of moral truth that must be present in the work through the actions of characters and covers the realistic skeletal of aesthetical muscle. Despite the differences between the two literary novelists, you can see that both challenge the social appearances. Therefore, we must re-read with a critical eye the criticism made by Machado in relation to Eça.
\end{abstract}

KEYWORDS: Naturalistic realism; carnavalized realism; moral and artistic figuration; Eça de Queirós; Machado de Assis.

O realismo naturalista, na literatura, apresenta-se como contraposição ao enfoque excessivamente subjetivista do Romantismo. Enquanto neste é o sujeito-autor que expressa seus sentimentos, sua visão de mundo, a unidirecionalidade de seus pontos de vista, naquele o sujeito-autor procura narrar com o máximo de objetividade (literária) os fatos existentes e persistentes numa dada realidade e num dado momento social, político e cultural. Existe, na opção literária realista-naturalista, uma preocupação em contextualizar, em manter os pés firmemente presos ao solo, deixando-os sujar de pó ou de lodo. Mas, principalmente, procurando caminhar junto com os fatos, assimilando suas verdades, mesmo que parcialmente.

Essa opção literária é filha de uma época. O século XIX pode ser caracterizado de vários modos. Mas um deles, certamente, predomina sobre todos: o modo libertário. A ideia de liberdade, ecoando sem parar desde a Revolução Francesa (1789), vai remexer os mais diversos tipos de mofos que impregnavam as estruturas sociais - políticas e culturais -

\footnotetext{
${ }^{1}$ Professor Titular da Universidade de Santa Cruz do Sul. Atua no Mestrado em Letras da Universidade de Santa Cruz do Sul. Doutor em Letras, UFRGS. E-mail: sergioschaefer@viavale.com.br
} 
e vai abrir portas e janelas para que o sufocante cheiro de naftalina seja substituído por novos ares respiráveis. Os atos libertários, umas vezes agem com mãos pesadas e radicalizadamente desajeitadas, outras, com dedos cuidadosos e irrequietamente mansos. É nesse contexto libertário que se situam as tendências do Realismo e do Naturalismo na literatura. Tomá-las como atos de libertação faz com as possamos enxergar além dos estreitos limites em que normalmente elas foram colocadas.

É bom acrescentar que qualquer processo de libertação pode tropeçar sobre si mesmo e cair a poucos metros de seu começo. E também dizer que não existe libertação total. $\mathrm{O}$ autor naturalista, ao incluir em seu programa literário o determinismo, levou a liberdade a suicidar-se. O que, aliás, pode ter o significado de um desejo de libertação radical e desesperado. Ou, num outro tipo de interpretação, pode significar que $\mathrm{O}$ Naturalismo fez da liberdade uma necessidade.

O primeiro e significativo ato de libertação promovido pelo realismo naturalista na literatura se concretiza como uma rejeição: o romantismo não dá mais conta literariamente da realidade e, portanto, é preciso negá-lo como opção estética válida. Isto fazem Flaubert, Zola, Eça de Queirós, Antero de Quental, Aluísio Azevedo, Machado de Assis e outros. Junto com essa negação afirmam-se avanços científicos, novos cuidados observacionais e experimentais, outra visão a respeito da dinâmica da natureza (seja esta física, vegetal, animal ou humana), novas estratégias, extremamente críticas, de análise das diversas instituições sociais (por exemplo, o casamento, a igreja católica), dos regimes políticos (por exemplo, o monarquismo, o republicanismo), das manifestações culturais, dos costumes etc.

O programa-plataforma das Conferências do Cassino Lisbonense apregoava:

Ligar Portugal com o movimento moderno, fazendo-o assim nutrir-se dos elementos vitais de que vive a humanidade civilizada; procurar adquirir a consciência dos fatos que nos rodeiam na Europa; agitar na opinião pública as grandes questões da filosofia e da ciência moderna; estudar as condições da transformação política, econômica e religiosa da sociedade portuguesa [...]. (MOISÉS, 1982, p. 197)

Esse movimento negador apresenta, basicamente, a marca de uma contestação desejante, isto é, ansiosa por mudanças. É, pois, uma negação positiva. O olhar e a pena do escritor estão voltados para um futuro diferente da realidade que está aí. O olhar percebe o existente e a pena procura colocá-lo no papel. Mas ambos desejam algo que não está aí, algo que ainda não é.

Como dois dos maiores romancistas da língua portuguesa, no século XIX - Eça de Queirós e Machado de Assis - se integraram nesse movimento negador? Essa será a questão que procuraremos esclarecer a partir de agora.

\section{A PALAVRA DADA E SUA NEGAÇÃO}

Os dois romances de Eça de Queirós, O crime do padre Amaro e O primo Basílio, tratam da negação positiva, a saber, são desejantes. O que eles desejam é a negação da negação da palavra dada. A força desse tema leva a ver com outro olhar as fraquezas decorrentes do modelo realista-naturalista adotado pelo autor para o desenvolvimento das tramas. Algo que o crítico Machado de Assis não viu.

O mesmo Machado afiado, que não viu a negação da negação da palavra dada em Eça, escreveu Memórias póstumas de Brás Cubas, um romance de além-túmulo. O autor das 
memórias, Brás Cubas, é um defunto autor. Enuncia a palavra morta. O presente da palavra é seu passado, sem futuro. Dar a palavra a um defunto, entretanto, faz de Machado um carnavalista menipeico. O recurso carnavalizante, inexistente em Eça, permite ao realismo machadiano distanciar-se poeticamente (esteticamente) da realidade e, assim, produzir uma obra de arte e não um mero álbum de fotografias, como em Eça. Machado pensa que a aísthesis só pode ser representada artisticamente se conseguir descolar-se do fato bruto, se passar por um processo de ressignificação psicológica e se atingir o status formal no qual as palavras dizem não dizendo, mostram não mostrando. E, ainda, ponto importante, se conseguir apresentar a "verdade moral".

Machado critica duramente o colega Eça por este ter se deixado afundar ingenuamente na antiartisticidade do modelo realista-naturalista. ${ }^{2} \mathrm{O}$ afundamento, que também é um encantamento, levou Eça a se perder num excesso de detalhes desnecessários para relatar os fatos. A literatura pode falar de esfregões de cozinha ou de lenços de cambraia, mas não precisa nos dizer de quantos fios se compõe um lenço ou um esfregão. Entretanto, o detalhamento da realidade não é o ponto mais frágil d'O crime e d'O primo. É inaceitável, diz Machado, que os atos dos personagens principais desses romances sejam apresentados de modo determinista, o que os faz cair fora do âmbito propriamente moral e que transforma os personagens em títeres ou em robôs infraguiados por forças obscuras da natureza e não pela vontade e pela liberdade.

Esqueçamos, por enquanto, a dura crítica de Machado aos dois romances de Eça. Procuremos lê-los com um olhar não-machadiano. Isso significa fazer um esforço para não colocar sob uma lente de aumento os detalhes realistas, a "exação de inventário", como diz Machado, ou o "carinho minucioso" com que são tratados por Eça o escuso e o torpe; e, mesmo, deixemos por enquanto de lado a ausência de personalidade moral que Machado percebeu nos personagens principais desses romances.

Eça de Queirós é um anticlerical lúcido. Em O crime do padre Amaro, nota a incoerência que existe entre a palavra e o comportamento daqueles que se dizem representantes de Deus na terra - os padres. Estes se apresentam aos fiéis como cavaleiros que se devotam inteiramente à causa da religião, entre outras coisas, por meio da castidade e, no entanto, desmentem este voto com uma prática contrária.

Não é o fato de um homem-padre manter relações afetivas, amorosas e carnais com uma mulher que perturba Eça. O que o deixa indignado, e sobre isso derrama o sarcasmo e a crítica ferina, é a quebra da palavra dada. Afinal, a palavra não paira no mundo como um flatus vocis e que deixa de ter sentido assim que some no silêncio. As palavras e seus significados persistem, mesmo que aparentemente evaporadas depois da fala ou ossificadas no grafismo da escrita. A palavra é viva. Eça lança os dardos certeiros no calcanhar-de-aquiles da igreja católica: o assassinato da palavra.

O crime do padre Amaro não é o de ter mantido relações sexuais com Amélia e nem de tê-la engravidado. Seu grande crime seria, então, o de ter encaminhado a morte do filho recém-nascido pelas mãos de uma "tecedeira de anjos"? Poderia ter sido, se a trama romanesca tivesse recebido encaminhamento diferente daquele dado pelo autor. Pela sequência da narração, percebe-se que o tema central do romance - a morte da palavra dada - não sofreu nenhum abalo. $O$ assassinato da criança é muito mais uma opção impactante do romancista Eça do que uma opção do personagem padre Amaro. O objetivo, sem dúvida, é criar no leitor uma profunda aversão por esse personagem. $O$ enfoque dado a Amaro, depois da morte do recém-nascido, não é o de ser um frio

\footnotetext{
2 Em 30 de abril de 1878, Machado de Assis publica na revista O Cruzeiro "O primo Basílio", uma ácida e devastadora crítica aos romances de Eça, de modo particular a O primo Basílio. (MACHADO DE ASSIS, 1959 , p. 154-179)
} 
assassino de crianças indefesas e, sim, o de continuar sendo um assassino da palavra dada. O crime do padre Amaro, e de todos os padres que se votam à castidade e que, na prática, a rejeitam, é a negação da palavra dada.

Ter ou não ter vocação para o sacerdócio não é o principal aspecto da questão. Tudo indica que Amaro não tinha vocação para assumir o sacerdócio - Eça deixa isso claro. O ponto é outro. Uma vez dada a palavra, ela precisa ser cumprida. O que Eça critica é a vida dupla de seu personagem principal, a hipocrisia que contamina sua personalidade, fundada ao mesmo tempo em duas vias possíveis: promessa de ser casto e de não ser casto. Eça crava até o fundo o punhal de sua crítica. Amaro, apesar de bem consciente do que fez, pretende continuar na duplicidade, só que com mais cautela depois da experiência tida com Amélia: as futuras mulheres com quem irá se relacionar deverão ser casadas, pois a eventual gravidez de uma delas poderá ser reputada ao marido.

Amaro e o cônego Dias - confidente de Amaro, professor de moral (!) e amante de S. Joaneira - trocam olhares cúmplices quando estão a conversar sobre isso, já no desfecho do romance:

Então junto deles passaram duas senhoras, uma já de cabelos brancos, o ar muito nobre; a outra, uma criaturinha delgada e pálida, de olheiras batidas, os cotovelos agudos colados a uma cinta de esterilidade, pouff enorme no vestido, cuia forte, tacões de palmo.

-- Cáspite! disse o cônego baixo, tocando o cotovelo do colega. Hem, seu padre Amaro?... Aquilo é que você queria confessar.

-- Já lá vai o tempo, padre-mestre, disse o pároco rindo, já as não confesso senão casadas! (EÇA DE QUEIRÓS, 2000, p. 1029)

Tudo passa, a vida dupla continua, a quebra da palavra dada é fato normal na vida do padre Amaro. É preciso somente ter mais cuidado, ser mais esperto. No fim de contas, Deus perdoa todos os nossos erros, inclusive aquele de dizer uma coisa e fazer outra.

Basílio não é o padre Amaro; Luísa não é Amélia. Em O primo Basílio, Eça de Queirós lança os dardos afiados contra a vida dupla e a quebra da palavra dada no casamento. Eça não coloca em cheque o casamento como instituição da sociedade organizada, com todas as funções que ele pode cumprir: reprodução da espécie humana, educação dos filhos, possibilidade de o homem e a mulher desenvolverem seus potenciais afetivos e sexuais, de aperfeiçoamento das identidades masculina e feminina etc. Por certo, Eça aceita o divórcio como uma das saídas para resolver problemas insolúveis entre os cônjuges, de vez que o divórcio é uma reformulação da palavra dada, assim como seria nova palavra um padre pedir dispensa do voto da castidade e deixar de ser padre. Eça, certamente, aceitaria as sábias palavras do quase nunca sóbrio Vinícius de Morais: " o amor é eterno enquanto dura". O que ele, mais uma vez, não aceita é a situação efetiva de uma negação esconder-se atrás de uma afirmação ou, então, de um sim tornar-se uma aparência. Eça abre armas contra as aparências. Luísa aparenta ser fiel a Jorge e tenta desesperadamente manter essa aparência. $O$ confronto que se estabelece entre ela e a empregada Juliana mostra isso com todas as letras: quer que o marido nunca chegue a saber do caso tido e mantido com Basílio. Quer que Jorge continue acreditando na palavra dada.

Por que Eça levou Luísa à morte? Quis, com isso, que nós, leitores, pensássemos ter sido a sua morte um castigo de Deus? Fosse assim, a intenção do autor estaria embasada num moralismo frouxo e rudimentar. Não. Aqui, novamente, o autor usa um recurso teatral, aguadamente trágico, para querer dizer outra coisa: a morte de Luísa é símbolo da morte da palavra dada. 
Se, por um lado, Eça de Queirós consegue desmascarar aparências fundamentais e crônicas persistentes na vida sacerdotal e na vida conjugal, por outro, ele não consegue superar a visão machista que permeia a sua lúcida análise. Por que o tema da morte da palavra dada deve cair tão pesadamente apenas nas principais personagens femininas Amélia e Luísa? Mesmo que Eça não pense ser a mulher a origem da ruptura de todas as palavras dadas, pode-se levantar uma suspeita: ele pensa que a mulher deve sofrer mais que o homem pelas consequências dessa quebra, consequências tão radicais que, inclusive, levam à morte física. Padre Amaro e Basílio continuam a vida de sempre, aqui e acolá com algum remorso cutucando suas consciências, mas envelhecendo junto com seu cinismo machista. Estaria Eça de Queirós, desse modo, reafirmando a visão tomista e cristã de que a mulher é a fonte de todos os males e que, por isso, merece sofrer mais que o homem? Se assim for, perdem seus romances a lucidez neles presente? Em absoluto, pois uma lucidez completa tornaria a palavra desnecessária e desnecessários romances tais como $O$ crime do padre Amaro e O primo Basílio. Digamos que Eça de Queirós lucidou por um instante e apenas com um olho. Com outro olho, e noutro instante, ele deslucidou. Cabe-nos a tarefa de criar novos instantes de lucidez em meio às sombras nas quais estamos imersos. Cabenos, nesse novo instante, abrir bem os dois olhos, mesmo sabendo que toda lucidez é precária e que qualquer olhar, mesmo feito com dois olhos, é sempre parcial.

Talvez não devêssemos mais ler estes romances de Eça como Machado de Assis os leu, isto é, como meras experiências de realismo naturalista antiartísticas e antiliterárias, relegando-as com desdém ao limbo de uma estética fracassada. Se Machado percebeu com grande perspicácia os pontos fracos dos personagens e dos enredos de Eça - de modo particular em O primo Basílio - isso não ofusca a lucidez que caracteriza tanto este romance como $O$ crime do padre Amaro. Quem sabe, não faltou a Machado a lucidez de perceber a lucidez de Eça?

\section{A NEGAÇÃO TUMULARMENTE NEGATIVA}

Memórias póstumas de Brás Cubas é um necromance. Os fatos marcantes nele narrados ou têm a ver diretamente com a morte - a começar pela morte do narrador, a morte da mãe, do pai, do amigo Quincas Borba e outras mortes - ou têm a ver com perdas, decepções e não-realizações. É uma narrativa feita de negações. O último capítulo do livro - "Das negativas" - sintetiza com exatidão a fundamentação tanatológica que o sustenta:

Este último capítulo é todo de negativas. Não alcancei a celebridade do emplastro, não fui ministro, não fui califa, não conheci o casamento. [...] Não tive filhos, não transmiti a nenhuma criatura o legado de nossa miséria. (MACHADO DE ASSIS, 1998, Cap. CLX)

A negação mais surpreendente do livro de Machado fica por conta da autoria das memórias. Estas são contadas por um defunto. Essa matriz negadora perpassa toda a narrativa e faz com que o ato rememorativo perca uma de suas funções básicas, que é a de abrir perspectivas para o futuro, para algo que também é uma negação, pois o futuro ainda não é. O futuro, entretanto, é uma negação positiva, enquanto o passado, revivido por um defunto, é uma negação negativa. A volta ao passado, feita por Brás Cubas, fica no passado, uma vez que a morte fecha todas as possibilidades. Não há mais futuro para quem morreu. A um falante ou escritor morto nada mais resta, a não ser deixar de lado toda e qualquer esperança. O que se perdeu em vida, não pode mais ser encontrado; o que não se realizou em vida, não se realizará jamais; as frustrações de qualquer tipo continuarão para sempre 
frustrações. Por isso, o romance de Machado é um necromance: lida com a negação tumularmente negativa.

Eça de Queirós não trabalha com a negação negativa. Nem poderia, de vez que seu modelo estético-literário é o realismo naturalista. Dentro dos limites desse paradigma, um indivíduo morto está morto e, portanto, relegado ao silêncio da tumba. O padre Amaro é um personagem vivo e a palavra morta - a negação do voto de castidade - anda de mãos dadas com a vida sacerdotal, formando com ela um duplo. O mesmo se dá com Luísa. Vive a duplicidade no casamento, carregando a palavra morta enquanto está viva.

Tanto no caso do padre Amaro, quanto no de Luísa, as portas do futuro estão abertas. Para o padre Amaro, o futuro apresenta três grandes possibilidades. Primeira possibilidade: pedir dispensa do voto de castidade e deixar de ser padre. Segunda possibilidade: depois da morte de Amélia e do assassinato do filho recém-nascido, confessar e arrepender-se, mudar o comportamento, continuar no sacerdócio, cumprindo, a partir de então, a palavra dada. E, terceira possibilidade, continuar padre e continuar a vida dupla de sempre. Eça, dono do personagem e indo até o fundo no anticlericalismo, opta por esta última via possível. Luísa também tem três possibilidades: abandonar o marido e viver com Basílio; esquecer o caso de adultério, assumi-lo como uma fraqueza passageira, e, daí em frente, voltar a ser fiel, cumprindo a palavra dada a Jorge, seu marido; e, em terceiro lugar, manter as aparências de fidelidade, continuando a vida dupla com outros Basílios. Eça, novamente adonando-se dos fios da trama romanesca, elimina as três possibilidades. Luísa morre e, com sua morte, morre o futuro.

Brás Cubas, o personagem defunto de Machado, está excluído, desde logo, do futuro. Seu presente é o passado. Os atos rememorantes saltam, um a um, do túmulo e se apresentam ao leitor com a fisionomia estampada por cadavérica objetividade. As coisas aconteceram assim e assim. Ponto final.

Não. Nada de ponto final. A melancolia (ou a hipocondria) de Brás Cubas, que, segundo Freud, pode encaminhar o eu à autodestruição, termina por vestir-se da provisoriedade do luto. O defunto salta do caixão e parece gritar: "Viva o carnaval!"

\section{A NEGAÇÃo CARNAVALIZANTE E O DITO NÃO DITO}

É Bakhtin, sem dúvida, o crítico literário que abriu nossos olhos para a importância da carnavalização na literatura. O tema é abordado com minúcias em Problemas da poética em Dostoievski. (BAKHTIN, 2010, p. 115-206) Os processos literários de carnavalização, que têm seus primeiros passos significativos dados na antiguidade através da sátira menipeia e dentro do campo sério-cômico, dão nova vida ao movimento narracional, fazendo-o acelerar ou desacelerar pela força da irreverência lúdica e da contestação, impregnadas, estas, de riso maldoso, ironia parodística e mordacidade corrosiva.

Os traços característicos da sátira menipeia, diz Bakhtin, são reencontrados na obra de Dostoievski, não do mesmo modo menipeu arcaico, mas reconfigurados por um processo de Aufhebung, isto é, renovados e conservados ao mesmo tempo. Bakhtin afirma que toda a obra dostoievskiana está tonalizada pelo gênero menipeu: "a menipeia dá, em verdade, o tom de toda a obra de Dostoievski." (BAKHTIN, 2010, p. 157) É claro que nisto não está dito que o tom carnavalizante esteja presente sempre com a mesma intensidade e variedade. Nos primeiros contos do escritor russo, o tom sátiro-carnavalesco está mais próximo do menipeísmo, enquanto que nos mais tardios ele se apresenta de modo mais livre. Essa maior liberdade torna-o mais sério que cômico, talvez semissério e semicômico. Esse avanço no rumo da seriedade se vê melhor nos grandes romances de 
Dostoievski. A carnavalização, mesmo trazendo junto de si o riso, a irreverência, o sarcasmo e a contestação, nos romances aparece revestida com véus de coloração roxa, mais para sexta-feira santa do que para sábado de aleluia. Assim, o sonho de Raskólnikov, após os assassinatos da velha agiota e de sua irmã, em Crime e castigo, é carnavalizante por vários motivos: porque a velha morta ri e gargalha, porque outras pessoas riem e cochicham, porque é um sonho e quebra barreiras convencionais, porque faz o espaçotempo borbulhar em "pontos de crise". (DOSTOIEVSKI, 1978, p. 317-318) É uma carnavalização impregnada de seriedade, pois o caso em questão é de importante densidade moral: matar ou não matar, ser ou não ser castigado pelo ato de matar, ser ou não ser necessária uma referência divina para a moralidade humana.

Perceba-se: carnavalizar, na literatura dostoievskiana, não é só encher livros de fantasias, deboches, alegria, descontrole e parodização. É, antes, levar a sério a seriedade da vida, fazendo-a, ao mesmo tempo, rir e chorar, maldizer bendizendo, angustiar-se ataraxicamente, pular de alegria na tristeza, corroer-se em incertezas certas, desdobrar-se em múltiplos eus sem perder a identidade, sentir-se seguro na insegurança.

Em Memórias, vemos Machado-artista vermemente a remexer as palavras com pena necrófila e tinta hipocondríaca, controlando o fogo da percepção viva a fim de que o produto final seja servido quente, mas não queime o papel e, junto com este, o artista. Falar sobre o real é preciso, mas não a tal ponto de chegarmos a saber "o número exato dos fios de que se compõe um lenço de cambraia ou um esfregão de cozinha." (MACHADO DE ASSIS, 1959, p. 157) Machado não se posiciona contra a realidade. É realista, e sempre o foi, mesmo nos tempos em que seu realismo vinha aquarelado com cores românticas. Não aceita, porém, que o real seja dito com todas as palavras.

A carnavalização, na literatura, não diz tudo. Diz e não diz. Brás Cubas, o morto cuja fala vem do outro mundo, conta tudo o que lhe aconteceu na vida, "sem temer mais nada". Mas não diz algo que só o leitor pode construir a partir do que foi dito: que há mortos-vivos na sociedade, presos ao passado, que atravancam a marcha para o futuro. $\mathrm{O}$ leitor pode se perguntar: sou um Brás Cubas? Sou alguém que apenas sabe monofonar a negação negativa? Ao usar o recurso carnavalizante do além-túmulo, Machado consegue transverter a negação negativa em negação positiva, isto é, ele nega a negação, torna-a desejante de algo diferente do que está aí determinado irrevogavelmente pela morte. Assim, da morte nasce a vida. Por isso, o último capítulo de Memórias, que é "todo de negativas", transforma-se no primeiro capítulo, feito de engatinhantes afirmativas, de um livro que Machado não escreveu e que poderia ser intitulado "Algumas esperanças de Brás Cubas renascido".

Memórias, de fato, diz não dizendo. A arte é afirmativa e, no entanto, vem tecida por meio de um não. Visto por este ângulo, o necromance de Machado abandona Thánatos e inicia novo romance com Eros.

Eça fala muito mais que Machado, mas também não diz tudo. Nesse ponto, os dois são irmãos, mesmo que de bico um com o outro. O que Eça não diz, dizendo: existem muitas pessoas que negam a palavra dada; é preciso negar essa negação se quisermos construir uma nova sociedade (de modo especial, para Eça, um novo Portugal). Como já foi dito antes, Eça trabalha literariamente a negação positiva, tanto quanto Machado. Mas o modo de fazê-lo é outro. Enquanto Eça arma a negação pelo caminho do realismo natural e cotidiano, Machado escolhe a inusitada via do realismo sobrenatural e fantástico. Machado está integrado no campo sério-cômico e deixa-se amarrar com uma fita verdeamarela na arcaica proposta literária da sátira menipeia. ${ }^{3}$ Eça pensa que é mais proveitoso

\footnotetext{
${ }^{3}$ Enylton de Sá Rego, em O calundu e a panaceia, procura vincular a obra literária da segunda fase de Machado de Assis (Memórias póstumas de Brás Cubas (1880/81), Quincas Borba (1891) e Dom Casmurro (1900) - os romances que analisa mais de perto) à tradição da sátira menipeia, mas de modo especial a Luciano de
} 
ficar namorando Eugênia Grandet e trocando ideias com l'abbé Mouret enquanto bebericam uma cerveja no Assommoir, numa roda onde não podem faltar Coupeau e Poisson.

\section{REALISMO NATURALISTA E DESFIGURAÇÃO MORAL}

Machado carrega a tinta quando se põe a criticar o perfil dos dois personagens principais de Eça: padre Amaro, de $O$ crime, e Luísa, de O primo. Resolve nocautear o colega português com um direto brasileiro direcionado sem dó nem piedade para aquilo que pensa ser o ponto mais fraco da antiarte queirosiana: a desfiguração moral.

Não se pode compreender, assim argumenta Machado, o terror que invade o padre Amaro com o nascimento do filho e, menos ainda, que o encaminhe para ser morto pelas mãos inescrupulosas de uma "tecedeira de anjos". Essa opção literária é "quimérica e impossível", diz Machado. (MACHADO DE ASSIS, 1959, p. 156) Por quê? Porque o ambiente em que vive padre Amaro aceita a concupiscência dos padres, aceita que tenham amásias, aceita a existência da "mulher do padre" e do "filho do padre". Então, por que se apavorar? Machado tem razão. O temor de Amaro é injustificado e o assassinato do recémnascido não encaixa no contexto de lassidão moral e de aparências sociais no qual o plot se desenrola. Do ponto de vista da construção romanesca, do quadro que lhe serve de lastro, da coerência que deve existir entre a construção e o quadro, a crítica machadiana acerta na mosca. Teria Eça cometido um deslize imperdoável? As coisas, entretanto, podem ser vistas de outro modo e, novamente, Machado não se deu ao trabalho de limpar os óculos. Vamos repetir o que já dissemos mais acima: Eça pretende criar no leitor funda aversão pelo personagem a fim de que a intencionalidade anticlericalista seja assimilada com todas as sílabas. A igreja católica é uma instituição feita de aparências e estas devem ser desmascaradas. O assassinato de um recém-nascido é um crime, sim, e dos mais hediondos. O objetivo real de Eça, porém, não é mostrar até que grau de crueldade pode chegar a natureza humana. Se fosse, a sequência do romance - após o assassinato da criança - seria bem outra. E o que Eça nos conta? Que o padre Amaro supera os fatos e continua o mesmo de antes e sempre: negador da palavra dada. Este é o ponto central do romance e não o assassinato do filho, por mais chocados que fiquemos com o fato.

Evidentemente, tudo isso que acabamos de dizer não tira a razão literária de Machado. E não o consegue porque a argumentação de sua crítica se apoia em um alicerce que, segundo ele, merece a atenção de qualquer escritor-artista e que confere à obra substancialidade. Trata-se da figuração moral dos personagens, pelo menos dos principais, daqueles que sustentam a narração.

Figurar moralmente não significa apenas apresentar personagens seguidores da norma moral. A figuração moral admite tanto o afirmador da norma como o negador da mesma. Um personagem imoral não desfigura a moral, pelo contrário, ele é uma demonstração viva da liberdade, tanto quanto demonstra sua liberdade aquele que, pelo seu comportamento, afirma a norma moral esforçando-se para segui-la à risca. Machado deixa isso claro quando, em Memórias, coloca como um dos pilares de sustentação desse romance Virgília, uma personagem belamente imoral. Machado não é moralista, contador de histórias santamente edificantes.

Porque o terror da opinião alheia e o assassinato do filho recém-nascido são introduzidos de forma gratuita na trama, Machado afirma que a "verdade moral" deixa de existir em O crime do padre Amaro. "Haverá aí alguma verdade moral?”, pergunta Machado.

Samosata. Para Sá Rego, foi o lucianismo o principal vetor a influenciar escritores sério-cômicos da Renascença em diante, tais como Erasmo, Robert Burton, Laurence Sterne, Lesage, Fielding - e, sem dúvida, no caso brasileiro - Machado de Assis. (SÁ REGO, 1989) 
(MACHADO DE ASSIS, 1959, p. 156) Verdade moral pode significar várias coisas, dependendo do paradigma ético que lhe serve de fundamentação teórica. Por exemplo, a verdade moral pode ser uma ou outra se for tomada como referência a Ética a Nicômaco, de Aristóteles, ou a Crítica da razão prática, de Kant, ou, então, a ética utilitarista de Bentham. Qual é o paradigma de Machado? Tudo indica que é principalmente este: o antinaturalismo. Fundar a moralidade no medo é, para Machado, afundá-la no determinismo natural e, assim, esvaziar o ato de sua substância propriamente moral. É o que acontece com o ato assassinante do padre Amaro. Matar o recém-nascido, no caso específico do padre Amaro, não constitui um ato imoral, pois, por ter sido motivado pelo medo, está de antemão excluído do campo da moralidade. Padre Amaro é um personagem amoral, isto é, o ato de matar a criança, ao ser efetivado, não teve um referencial moral. Por isso, passado o medo (natural), e o caso tido com Amélia e o assassinato do filho acomodados pelo (natural) andamento do mundo, padre Amaro volta a ser o de sempre, porém, rescaldado, pretende ser mais cuidadoso nos futuros relacionamentos com as mulheres.

Machado rejeita personagens amorais. ${ }^{4}$ Para ele, a amoralidade literária é um produto típico do modelo naturalista. Luísa, de O primo Basilio, vem a ser outro desses personagens: "a Luísa - força é dizê-lo - a Luísa é um caráter negativo, e no meio da ação ideada pelo autor [Eça de Queirós], é antes um títere do que uma pessoa moral." (MACHADO DE ASSIS, 1959, p. 159)

Machado concede-lhe nervos e músculos (naturais), mas não paixões, nem remorsos e nem consciência (moral). Luísa é movida a medo. O combustível natural dos seus atos é o medo, o mesmo que levou o padre Amaro a fazer o que fez. "Luísa não tem remorsos, tem medo"; "Medo, sim; o que ela tem é medo." (MACHADO DE ASSIS, 1959 , p. 163; 174) Tanto um como outro personagem desfiguram a moralidade e colocam a literatura no campo do determinismo natural, fazendo com que a obra literária deixe de ser obra de arte. Segundo Machado, arte, sem parâmetros morais, não é arte. Seria Luísa personagem de um tratado literário de neurologia e de miologia? Para o afiado Machado parece ser.

\section{REALISMO CARNAVALIZADO E FIGURAÇÃO MORAL}

Machado de Assis rejeita personagens amorais, mas não personagens imorais. Essa diferença precisa ser bem guardada, pois é ela que esclarece a polêmica entre o escritor brasileiro e o lusitano.

$O$ ato imoral se caracteriza pela negação consciente de uma norma de comportamento estatuída como boa ou certa para a convivência básica dos humanos organizados socialmente. A norma moral é histórica, ou seja, mutável, (quase sempre) estabelecida de modo racional e com alguma garantia universalista para dado grupo humano. Uma dessas normas é, sem dúvida, esta: cumprir a palavra dada. Isso não significa, em absoluto, que uma palavra dada seja dada para sempre. O "para sempre" roubaria da moralidade seu caráter histórico-mutável. Entretanto, enquanto a palavra dada está dada, ela pede seu cumprimento. Amanhã ou depois ela pode ser revista e refundada por nova palavra dada. É, entre outros, o caso do divórcio, quando o casal solicita anulação do compromisso conjugal e homem e mulher estão livres para constituírem nova palavra dada. Enquanto a palavra dada vigora, qualquer ato negador da mesma pode ser considerado imoral.

Eça, no Crime, lança aqui e acolá razoáveis indícios para dar a entender ao leitor que Amaro não poderia ser diferente do que é, uma espécie de robô humano determinado

\footnotetext{
${ }^{4}$ Mas não tem nada contra personagens imorais. Virgília e Brás Cubas são a prova.
} 
pela sua natureza particular (e pelo meio) a ser mulherengo, falso, duplo, hipócrita, cínico e assim por diante. Aquilo que estamos acostumados a saber sobre o modelo realistanaturalista. Mais ou menos parecido ao que Aristóteles dizia do par potência-ato: na semente já está contido o futuro desdobramento da planta e dos frutos maduros.

Entretanto, se o romance de Eça fosse apenas isso, a mensagem anticlerical nele presente perderia o interesse e a importância; deixaria de ter a dimensão contestatória; e não teria olhos para o futuro, para algo que ainda não é, ou seja, para algo não determinado pelo passado ou pelo presente. Por isso, não se pode ler $O$ crime, e mesmo $O$ primo, tendo como referência exclusiva o modelo realista-naturalista, que, diga-se, realmente orientou Eça para estruturá-los.

Para não deixar escapar entre os dedos o lado contestatório dos dois romances de Eça, precisamos relê-los com um olho atento no realismo determinista e outro atento no realismo queirosiano, contestador e quase-carnavalizado. Se conseguirmos fazer isso, teremos um terreno aberto para distinguir o que é, nesses romances, amoral e imoral. Em grande parte, eles são amorais e é o modelo naturalista-determinista que os faz ser assim. Aqui, Machado acerta. De outra parte, não menos significativa, eles são imorais e será essa imoralidade que dará a Eça a chance de criticar literariamente a moralidade aparente do baixo clero católico português e aquela do casamento burguês e pequeno-burguês. Quando Amaro nega a palavra dada (manter-se casto como padre), ele age imoralmente. Quando Luísa nega a palavra dada (manter-se fiel ao marido no casamento), ela age imoralmente. ${ }^{5}$

Se os atos de Amaro e Luísa fossem tão-somente amorais, isto é, determinados por forças obscuras da natureza humana (medo, desespero, instinto, inconsciente, código genético etc.), Eça teria que dar o braço a torcer ao fatalismo burro. Seu anticlericalismo iria por águas abaixo. Suspiraria, conformado: "O mundo é assim mesmo..."

Machado de Assis não soube, realmente, ler com a atenção necessária $O$ crime do padre Amaro e, menos ainda, O primo Basílio. Desatencioso, não percebeu suas "verdades morais". Mas as leituras dos livros de Eça lhe possibilitaram dar-se conta de algo fundamental: o realismo literário precisa abandonar o naturalismo determinista e tornar-se arte. Somente assim a "verdade moral" voltará a brilhar de forma inteiriça. Convencido disso, arregaça as mangas e começa a escrever Memórias póstumas de Brás Cubas.

Em Memórias, a personagem mais bem trabalhada, do ponto de vista da imoralidade, é Virgília. É ela quem, de fato, define aquilo que o realismo machadiano entende por "verdade moral". Mulher típica da classe média bem situada, consciente do que faz, raposina, infiel ao marido Lobo Neves por opção. Nem ela, nem Brás Cubas se instalam na casinha da Gamboa por medo, mas para melhor usufruírem a imoralidade do seu relacionamento:

A casa [a casinha da Gamboa, “um brinco!’] resgatava-me tudo; o mundo vulgar terminaria à porta; -- dali para dentro era o infinito, um mundo eterno, superior, excepcional, nosso, somente nosso, sem leis, sem instituições, sem baronesas, sem olheiros, sem escutas, -- um só mundo, um só casal, uma só vida, uma só

\footnotetext{
5 Nos tempos que correm hoje, a inflexibilidade dos binários fidelidade-infidelidade no casamento está passando por um processo importante de amaciamento. Como outros conceitos, este par conceitual está sendo ressignificado. O processo ainda está longe da clareza, mas tudo indica que, para esta clarificação, serão levadas em conta as dimensões sexuais e afetivas masculinas e femininas, como também uma mudança radical no conceito opressivo de pecado, de infernal memória e tão útil às diversas religiões para o controle das consciências. Nietzsche que o diga. A questão do celibato dos padres católicos continua, por enquanto, vetada à discussão. E continuará assim fechada enquanto o principal ponto da questão estiver assentado nos bens materiais da igreja católica e não na dimensão propriamente humana dos celibatários.
} 
vontade, uma só afeição, -- a unidade moral de todas as coisas pela exclusão das que me eram contrárias. (MACHADO DE ASSIS, 1998, p. 169)

Machado é um escritor realista e, como tal, procura narrar os fatos assim como estes se dão numa dada realidade - aqui, a sociedade carioca do século XIX. O recurso carnavalizante que usa - um defunto narrador - facilita essa tarefa, uma vez que as coisas podem ser ditas às claras, "sem temer mais nada". Não é, pois, um defunto que narra os fatos, mas um vivo bem vivo. Ao dar a um morto a responsabilidade da narração, Machado engancha uma rasteira de mestre no naturalismo, uma vez que - e isso já dissemos antes para um naturalista um morto está morto e não fala mais. A inverossimilhança, jogada de bruto sobre o leitor, é quase que imediatamente esquecida pela força verossímil dos fatos narrados. O recurso carnavalizante é um facilitador, mas num sentido extremamente importante: o autor se sente mais livre para dizer o que quer. Geralmente, o dito é construído por meio do modo satírico, cômico-sério, semicômico, semissério; muitas vezes mais sério que cômico, como nos grandes romances de Dostoievski, Crime e castigo, Os irmãos Karamázov; ou mais cômico que sério, tal como fez Cervantes em Dom Quixote, ou, ainda, bastante sério, como na Divina Comédia de Dante Alighieri.

Machado mistura comicidade com seriedade. É sátiro-cômico em quase todos os minicapítulos do livro, desde o capítulo II, quando conta sobre o emplasto. Mas a morte da mãe o deixa sério e hipocondríaco. Não ter tido filhos e, assim, não ter transmitido "a nenhuma criatura o legado de nossa miséria" é, antes, um desabafo aliviado: não contribuiu para a natural reprodução da espécie humana; é, antes, mais um golpe bem dado no naturalismo literário. Mas o fato mais sério do livro, e o mais prazeroso, fica por conta da relação imoral tida e mantida com Virgília.

Brás Cubas também é imoral, mas de uma imoralidade diferente. Solto no mundo, boa-vida, descompromissado, não tem vínculos morais com nenhuma palavra dada. $\mathrm{O}$ saber bacharelesco adquirido em Coimbra é jogado às traças. Marcela e as outras mulheres de passagem são lenha para atiçar o fogo e água para apagá-lo. O não-emprego e o nãotrabalho são um céu numa sociedade estruturada burguês e sabiamente e que concede a alguns afortunados o privilégio de não precisarem comprar o pão com o suor do seu rosto. Brás Cubas não-ministro, não-marquês, não-barão, sem dúvida, lhe diminuem as chances de uma dolce vita com um plus de dulçura, mas não é o fim de tudo, pois ainda hão por aí Virgílias para tornar a existência de um bon vivant muito mais boníssima e dulcérrima. Errado, não são Virgílias, no plural. Virgília é única - a Virgília.

Machado de Assis apresenta diferentemente as "verdades morais" de Brás Cubas e de Virgília e isso lhes confere personalidades literárias diferentes. Brás Cubas é imoral em relação ao seu país e à sociedade e é o gatilho armado para que a imoralidade de Virgília seja disparada. Virgília é imoral em relação à palavra dada a Lobo Neves, seu marido, e pretende tirar o máximo proveito do gatilho brascubasiano bem armado em sua direção.

Em Memórias, as "verdades morais" são claras e distintas. Mas, principalmente, são evidentes. Bem distantes da ambiguidade clara-escura das "verdades morais" apresentadas por Eça nos seus dois romances, ambiguidade essa, repita-se, decorrente do modelo escolhido para serem contadas literariamente - o realismo naturalista.

Seria Machado de Assis um cartesiano? Longe disso. A clareza, a distinção e a evidência podem ser apenas luzes trêmulas de algum leitor avisado tentando entender a mensagem machadiana. O nosso grande escritor lida com razões, sim, mas são razões vindas do coração de certa classe social preocupada em manter seus privilégios e suas aparências. E como reza o dito popular, contrariando Descartes: o coração tem razões que a razão desconhece. Desconhece, porque não tem coração. 
Este coração está morto, mas insiste em continuar batendo. Não quer aceitar o lugar que a marcha da história lhe reserva - o cemitério. O bondoso Machado resolve, democraticamente, abrir-lhe um espaço artístico para se manifestar. Convence o editor da Revista Brazileira, Nicolau Midosi, a publicar, passo a passo, as memórias desse coração morto, enterrado e já vermificado. O resultado será um epitáfio nunca dantes visto em terras brasileiras.

Nem todos os que leram aquelas Memórias souberam perceber o impacto carnavalizante nelas presente. Eça leu e percebeu. Mas não perdeu a elegância anglo-lusa. Ajeitou o monóculo, torceu os fios do bigode e falou aos botões do colete: "Prefiro o fado ao carnaval..."

\section{REFERÊNCIAS}

BAKHTIN, Mikhail. Problemas da poética de Dostoievski. Trad. Paulo Bezerra. 5. ed. rev. Rio de Janeiro: Forense Universitária, 2010.

DOSTOIÉVSKI, Fiódor. Crime e castigo (v. I). Trad. Natália Nunes. São Paulo: Abril Cultural, 1979, p. 317-318.

1997.

Presença da literatura brasileira. São Paulo: Bertrand do Brasil,

EÇA DE QUEIRÓS. O crime do padre Amaro. (Edição crítica das obras de Eça de Queirós preparada por Carlos Reis e Maria do Rosário Cunha). Lisboa: Imprensa NacionalCasa da Moeda, 2000.

O primo Basílio. São Paulo: Ateliê Editorial, 2001.

MACHADO DE ASSIS. "O primo Basílio". In: Crítica literária. (Obras completas de Machado de Assis, v. 29). São Paulo: Ed. Mérito, 1959, p. 154-179.

1998.

Memórias póstumas de Brás Cubas. São Paulo: Ateliê Editorial,

REIS, Carlos; CUNHA, Maria do Rosário (ed.). Introdução. In: O crime do padre Amaro. (Ed. Crítica das obras de Eça de Queirós). Lisboa: Imprensa Nacional-Casa da Moeda, 2000, p. 15-91.

MOISÉS, Massaud. A literatura portuguesa. São Paulo: Cultrix, 1982.

SÁ REGO, Enylton de. O calundu e a panaceia. Machado de Assis, a sátira menipeia e a tradição luciânica. Rio de Janeiro: Forense Universitária, 1989.

Recebido em 23/03/2013.

Aprovado em 17/10/2013. 